
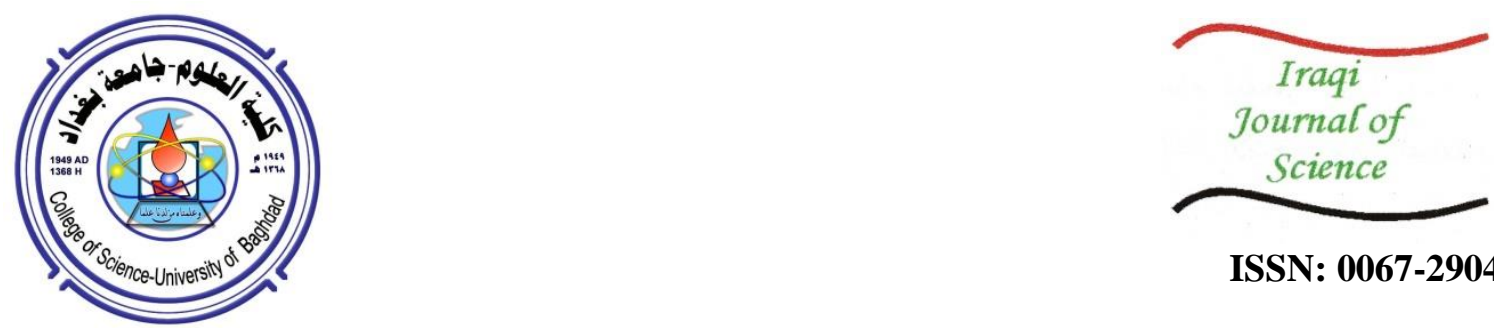

ISSN: 0067-2904

\title{
Activation and Enhancement of the Performance of Iraqi Ca-Bentonite for Using as Drilling Fluid in Iraqi Oil Fields
}

\author{
Ahmed Sattar Ibrahim*, Mayssaa Ali Al-Bidry \\ Department of Petroleum Technology, University of Technology, Baghdad, Iraq
}

Received: 20/8/2019

Accepted: $21 / 1 / 2020$

\begin{abstract}
In this study, Iraqi bentonite taken from Trefawi area/ Al-Anbar region province/ Iraq, was activated to enhance its rheological and filtration properties and increase its quality by decreasing the non-clay minerals (impurities), in order to be used in Iraqi oil companies instead of commercial bentonite. Bentonite was characterized by $\mathrm{X}$-ray diffraction (XRD), X-ray fluorescence (XRF) and particle size distribution (PSD) before and after activation to show the effects on its mineral and chemical properties. The rheological properties of bentonite were enhanced by using different weights $(0.4,0.5,0.6,0.7$ and $0.8 \mathrm{gm})$ of sodium carbonate $\left(\mathrm{Na}_{2} \mathrm{CO}_{3}\right)$, whereas the filtration properties were enhanced by using different weights $(0.5,1,1.5 \mathrm{gm})$ of high viscous-carboxy methyl cellulose (CMC-HV) and different weights $(0.5,1,2$ $\mathrm{gm}$ ) of low viscous-carboxy methyl cellulose (CMC-LV). The results showed that the rheological properties of Iraqi bentonite were enhanced and met the specifications of the American Petroleum Institute (API) when $0.7 \mathrm{gm}$ of $\mathrm{Na}_{2} \mathrm{CO}_{3}$ was added. The filtration properties were also enhanced and satisfied API specification when $0.5 \mathrm{gm}$ of CMC-HV and $2 \mathrm{gm}$ of CMC-LV were added. Therefore, Iraqi bentonite has the potential to be used as drilling fluid in oil fields.
\end{abstract}

Keywords: Iraqi bentonite, bentonite Activation, Drilling fluid, Rheological properties, Filtration properties

$$
\begin{aligned}
& \text { تنشيط و تحسين ادائية بنتونايت الكالسيوم العراقي لأستعماله كسائل حفر } \\
& \text { احمد ستار ابراهيم" , ميساء علي البدري }
\end{aligned}
$$

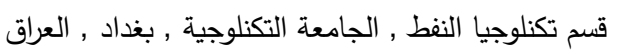

في هذه الدراسة, البنتونايت العراقي المأخوذ من موقع طريفاويا محافظة الانبارا العراق قد تحسن و تتثط تم تتشيطه لزيادة خواصه الريولوجية و خواصه الترشيحية و زيادة جودنه بتقليل المعادن الغير طينية (الثوائب) لكي يستعمل في شركات النفطية العراقية كبديل للبنتونايت الاجنبي.

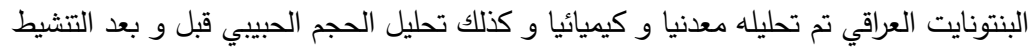

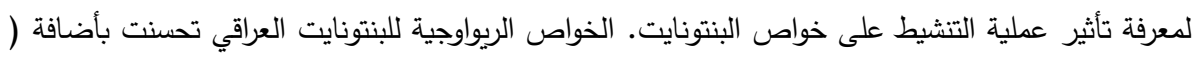

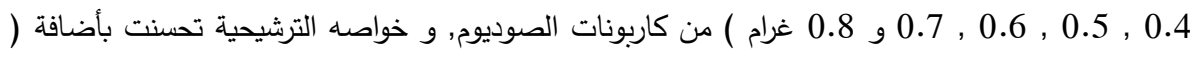

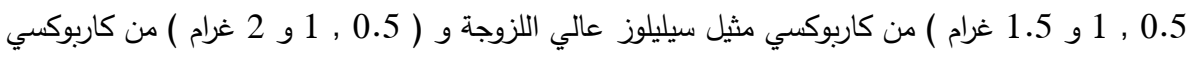

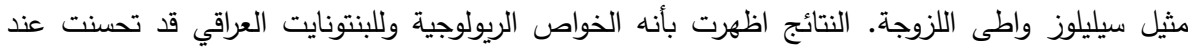




$$
\begin{aligned}
& \text { اضافة } 0.7 \text { غرام من كاربونات الصوديوم, كنلك النتائج اظهرت بأنه الخواص الترشيحية للبنتونايت العراقي قد } \\
& \text { تحسنت عند اضافة } 0.5 \text { غرام من كاربوكسي مثيل سيليلوز عالي اللزوجة و } 2 \text { غرام الفام من كاربوكسي مثيل } \\
& \text { سيليلوز واطئ اللزوجة. لذلك البنتونايت العراقي يمكن استعماله كسائل حفر . }
\end{aligned}
$$

\section{Introduction}

During drilling of oil and gas wells, fluids are used to lubricate the drill bit, maintain hydrostatic pressure, transmit sensor reading, remove rock cuttings, and inhibit swelling of reactive clay-based shale formations. Aqueous drilling fluids (water-based mud) are an environment friendly and more economic than the non-aqueous type (oil-based mud and synthetic-based mud). In order to achieve the optimum performance of any mud during operations, the physical as well as chemical properties of the mud must be carefully controlled; viscosity, gel strength, fluid loss are of particular importance parameters of drilling fluid. Also, the clay surface chemistry and that of various drilling fluids must be controlled [1]. The ability of the drilling mud to perform its functions depends entirely on its viscosity. Without viscosity, all weighting materials and drill cuttings would settle on the bottom of the hole as soon as circulation is stopped [2].

Bentonite clay is considered as a suitable and promising material used as drilling fluid because it makes the drilling fluid viscous [3] and has optimal properties such as ion-exchange capacity, swelling, surface area, plastic viscosity, and thixotropy [4]. Bentonite is made of two building blocks; the aluminum octahedral sheet and the silica tetrahedral sheet [5]. Bentonite is a clay deposit consisting of smectite minerals usually dominated by montmorillonite which has a very wide range of industrial applications [6]. The montmorillonite lattice is negative in charge, owing primarly to isomorphous replacements of ions within the structure. This negative charge is balanced by cations, which are held on the surface of the flakes and clay, and can be readily exchanged. The cations that are most commonly found in nature are sodium and calcium [7]. Bentonite adsorbs water in the interlayer region and this adsorption process initiates swelling. The degree of swelling of the platelets depends on the type of cations in the interlayer region. If the interlayer cations are monovalent and strongly hydrated, such as $\mathrm{Na}^{+}$or $\mathrm{Li}^{+}$, the inter-platelet repulsion will be strong and the swelling capacity will be high. Na+ content was found to be the most influential factor for enhancing the rheological properties of bentonite. In addition to the ability of $\mathrm{Na}^{+}$contained in bentonite to adsorb water, it also increases viscosity and forms thixotropic suspensions with a good gel strength. Unlike Na-bentonite, Ca-bentonite has low swelling capacity and forms unstable suspensions with high settling rates [8].

Calcium bentonite can be converted to sodium bentonite by treatment with sodium carbonate (a process called sodium activation). This activation, if conducted properly, can result in a bentonite that exhibits many of the characteristics of natural sodium bentonite [9]. By sodium activation or by introducing some polymer additives, it is possible to upgrade some Ca-bentonite to meet the API standard (30 cP minimum viscosity at $600 \mathrm{rpm} ; 15 \mathrm{~cm}^{3}$ filtration loses, and $33 \mathrm{ml}$ swelling index) [10].

A number of researchers attempted to enhance the performance of Iraqi bentonite in order to use it as drilling fluid. AL- Ajeel et al. (2012) tried to activate calcium bentonite (high grade calcium montmorillonite claystone) from Wadi Bashira region, Westren Desert, using sodium carbonate through a dry grinding procedure. They subsequently evaluated the product for use as drilling fluid. The results showed that the rheological properties of the activated sample were highly improved, but the sample failed to fulfill the API drilling fluid requirements [11]. Rasin et al. (2013) studied the activation conditions of Iraqi Bentonite from Qara Tappah formation at various ratios for converting it to the gelling form. Soda ash was used in the activation process with ratios of $2.5,5$ and $7.5 \%$. The best result for obtaining the gelling form in the limit of experimental work was found at the activation ratio of $7.5 \%,[12]$.

The aims of this study were to enhance the performance of Iraqi bentonite by enhancing the properties of its main mineral component (montmorillonite), decreasing its impurities (quartz and calcite), and enhancing its rheological and filtration properties in order to use it in Iraqi oil companies instead of commercial bentonite. Önal and Sarikaya (2017) [13] investigated the activation of local Turkish calcium bentonite of Kütahya Formation, which showed significant changes in crystal structure, chemical composition, and porosity with $\mathrm{H}_{2} \mathrm{SO}_{4}$ activation, realized by heating its acidic aqueous suspension at $97{ }^{\circ} \mathrm{C}$ for 6 hours [13]. Al-Essa (2018) studied the activation of Jordanian bentonite by hydrochloric acid at room temperature. The results demonstrated that bentonite was successfully activated and the adsorption efficiency was strongly affected by several parameters, such 
as $\mathrm{pH}$ and temperature of the solution and adsorbent dosage. The efficiency was increased with the increase in the temperature of the solution and the adsorbent dose [14].

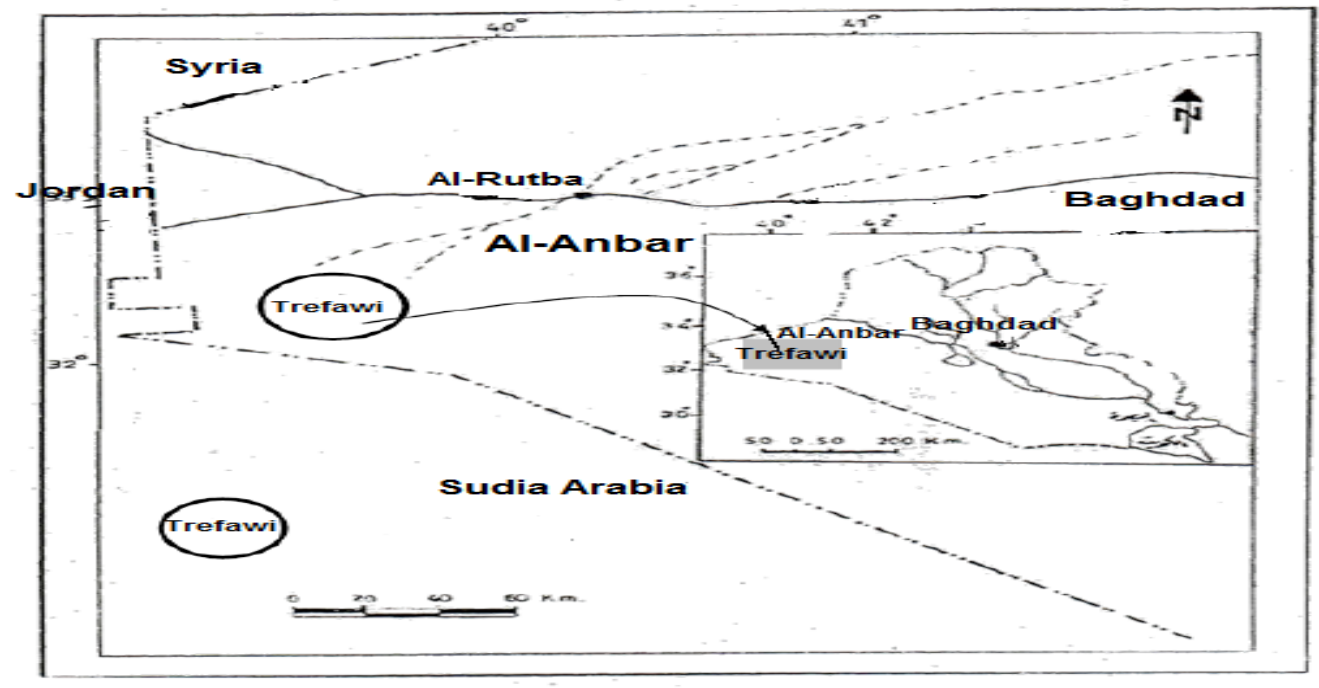

Figure 1 Geological Map of Trefawi Area.

\section{Experimental Work \\ Determination of Drilling Fluid Properties \\ Rheological properties}

This test was performed to measure the viscosity at 1, 2, 3, 6, 10, 20, 30, 60, 100, 200, 300 and 600 readings of the Viscometer, plastic viscosity, yield point, $10 \mathrm{~min}$ and $10 \mathrm{sec}$ gel strengths. The equipment used was a viscometer (OFFITE model 900) while the materials were freshly prepared. The freshly prepared mud was poured into the sample cup of the viscometer. The rotor was allowed to rotate for few seconds for stabilization. Then the rotor sleeve was immense until the mud touched its scribed line. The mud button was pressed and the viscometer automatically carried out all the measurements above [2].

\section{Filtration properties}

The low pressure-low temperature filtration test, based on the API standard, was carried out at surface (room) temperature and 100 psi pressure for 30 minutes. The low pressure-low temperature filter press consisted of a cylindrical cell (3-inches in internal diameter (ID) and 5-inches high) to contain the formulated drilling mud. The bottom of the cell was fitted with a sheet No. 50 filter paper and filled with the clay mud sample to be measured. After the necessary connections, a pressure of 100 psi from an air compressor pump was supplied to the top of the cells. With a measuring cylinder placed beneath the cell, the filtrate through the filter paper was collected over a period of 30 minutes and recorded in $\mathrm{ml}$; also the thickness of mud cake was measured in $\mathrm{mm}$.

\section{Density determination}

The density of the mud was measured with a mud balance. The density was read at the left hand edge of the sliding weight and recorded.

\section{pH determination}

The $\mathrm{pH}$ test is a measurement of the concentration of hydrogen ions in aqueous solutions. This was performed by a $\mathrm{pH}$ meter after calibration. The probe was placed in the mud sample and the reading was taken after the needle was stabilized (the probe was washed clean before re-use). Also, $\mathrm{pH}$ was additionally tested by $\mathrm{pH}$ measurement papers.

\section{Stability determination}

The stability of the drilling fluid was measured by leaving the Solution of drilling fluid [ $22.5 \mathrm{gm}$ of bentonite and $350 \mathrm{ml}$ of distilled water] for $24 \mathrm{hrs}$ in a $250 \mathrm{ml}$ cylinder, as shown in Figure-2. The volume of the liquid separated from the drilling fluid was measured and applied in the following equation:

$$
\text { Drilling Fluid Stability } \%=\frac{\text { separated liquid volume }}{250 \mathrm{ml}} * 100
$$




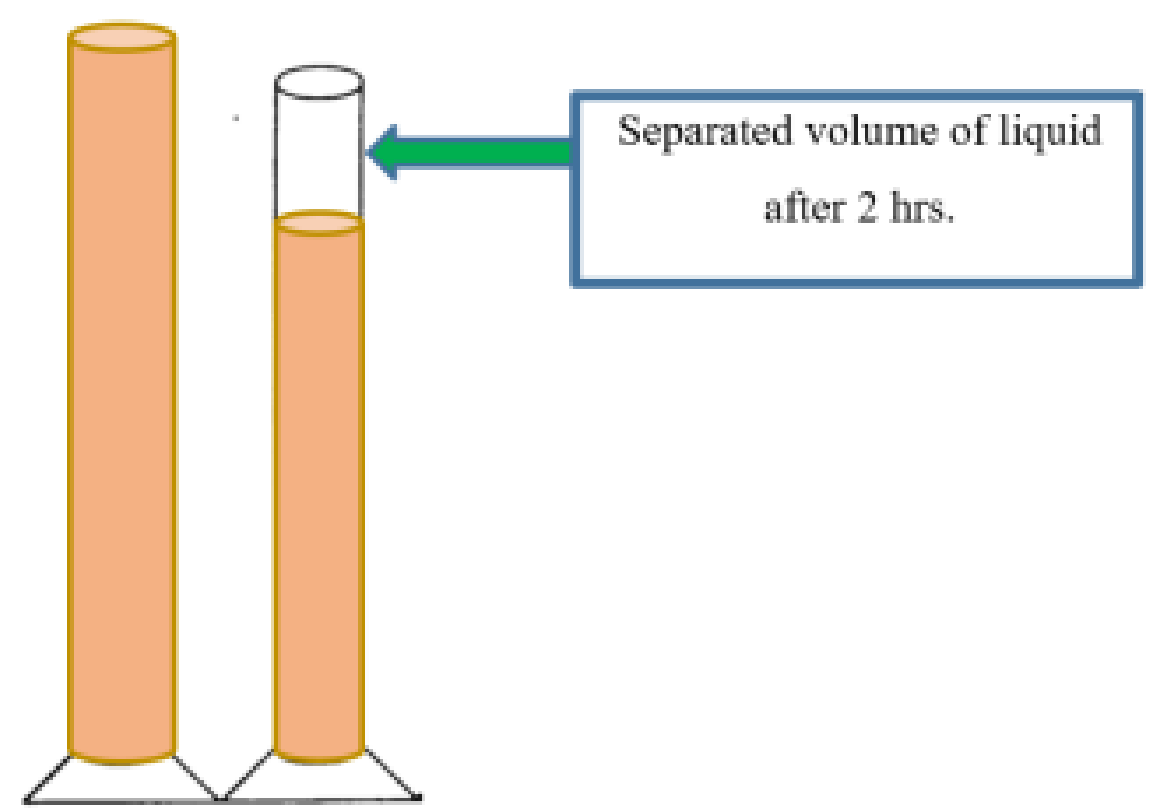

Figure 2-Stability Measurement of the Solution of Drilling Fluid [15].

\section{Bentonite specifications for using as drilling fluid}

Bentonite used for drilling fluids must meet the specifications set by the API, based on Wyoming natural sodium bentonite and the Oil Companies Materials Association (OCMA), which is used for lower quality clays, including Na-exchanged bentonites. These specifications are related to the viscosities of suspensions of fixed solids content, requiring the measurement of apparent viscosity, plastic viscosity, yield value, and the filtrate loss of a suspension at the same solids content. Specifications are shown in Table- 1.

Table 1 Specifications of Bentonite for Usage as Drilling Fluid [16].

\begin{tabular}{|c|c|c|}
\hline Measurement & API & OCMA \\
\hline Viscometer dial reading at 600 rpm & $30 \mathrm{~min}$ & $30 \mathrm{~min}$ \\
\hline Yield point/plastic viscosity ratio & $3 \mathrm{max}$ & $6 \mathrm{max}$ \\
\hline Filtrate volume & $15 \mathrm{ml}$ & $16 \mathrm{ml}$ \\
\hline Residue $>75 \mu \mathrm{m}$ & $4 \% \mathrm{max}$ & $2.5 \% \mathrm{max}$ \\
\hline Moisture & $10 \% \mathrm{max}$ & $13 \% \mathrm{max}$ \\
\hline
\end{tabular}

Measurements of these specifications were made on the suspensions of $22.5 \mathrm{~g}$ of bentonite in $350 \mathrm{ml}$ of water [16].

\section{Bentonite characterization}

Iraqi bentonite taken from Trefawi area in Akashat formation/AL-Anbar region/ Iraq was provided by the Iraqi geological survey company. In this study, Iraqi bentonite was grinded to powder and sieved to size $<75 \mu \mathrm{m}$ (200 mesh) [17], then dried in oven at $180{ }^{\circ} \mathrm{C}$ for $12 \mathrm{hr}$ [18]. $22.5 \mathrm{gm}$ of bentonite was mixed with $350 \mathrm{ml}$ [19] of distilled water for 20 minutes and left for $24 \mathrm{hr}$ to hydrate [20]. Then, the rheological properties of mud were measured.

The mineralogical composition of the clay fractions $(<75 \mu \mathrm{m})$ of the original and treated montmorillonite-rich clay was determined using type $61007000 \mathrm{X}$-ray diffraction. The major elements were measured from the bulk samples and the bentonite fraction $(<75 \mu \mathrm{m})$ of the original and treated montmorillonite-rich clay using type1800 sequential XRF spectrometer. Also, bentonite was characterized by 2000s Malvern Mastersizer to show the particle size distribution before and after treatment. XRD, XRF and particle size distribution analyses were carried out in the Iraqi Geological Survey/Central, Laboratories Department. 


\section{Bentonite enhancement}

\section{Enhancing the rheological properties of Iraqi bentonite}

In this test, $0.4,0.5,0.6,0.7$ and $0.8 \mathrm{gm}$ of $\mathrm{Na}_{2} \mathrm{CO}_{3}$ were mixed with $22.5 \mathrm{gm}$ bentonite and $350 \mathrm{ml}$ of distilled water for 20 minute in Hamilton Beach Mixer and left for $24 \mathrm{hs}$ in a closed container to ensure good dehydration. After that, the rheological properties of the mixture were measured.

\section{Enhancing the filtration properties of Iraqi bentonite}

In order to enhance the filtration properties, $0.5,1$ and $1.5 \mathrm{gm}$ of low viscous-carboxy methyl cellulose (CMC-LV) were added to the mixture of $0.7 \mathrm{gm}$ of $\mathrm{Na}_{2} \mathrm{CO}_{3}$ and $22.5 \mathrm{gm}$ of bentonite with $350 \mathrm{ml}$ of distilled water. After that, 0.5, 1 and $2 \mathrm{gm}$ of CMC-HV were added to the best result of CMC-LV addition.

\section{Results and Discussions}

\section{Characterization of raw bentonite}

XRD analysis showed that Iraqi bentonite contains montmorillonite and palygorskite as main minerals in addition to quartz and calcite as impurities (Figure-3).

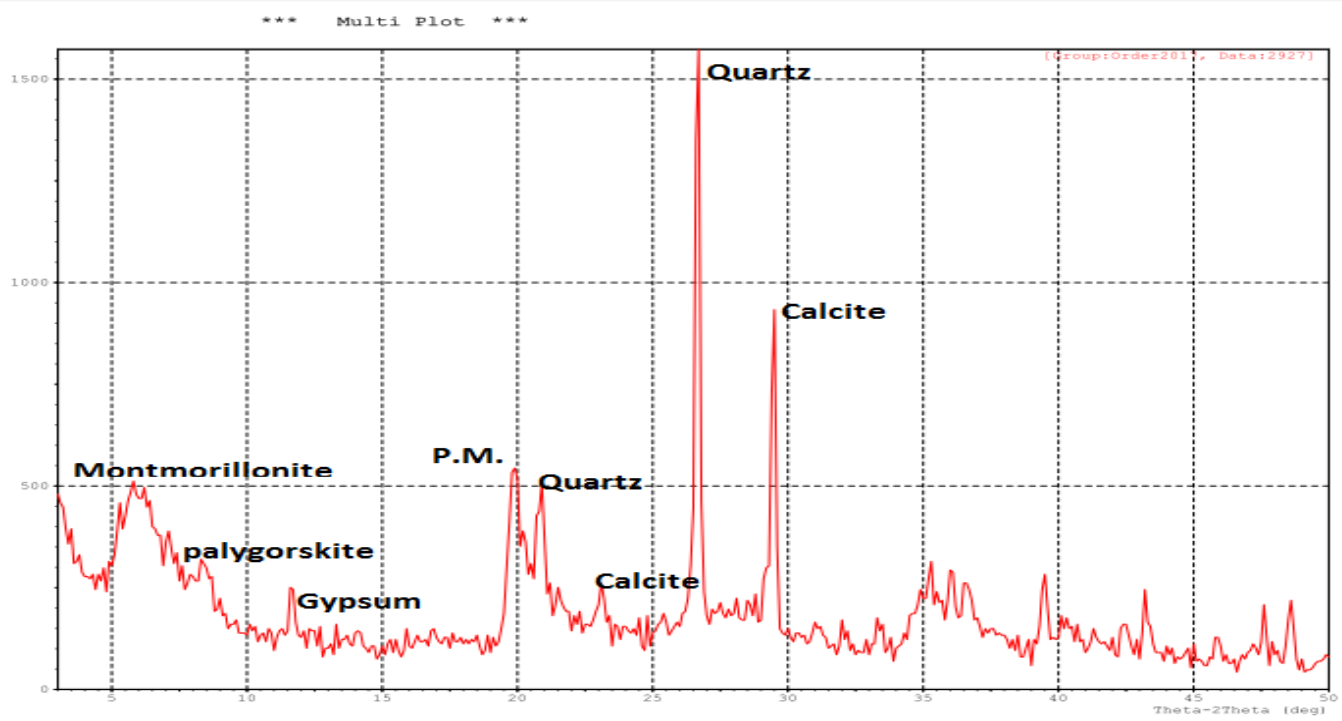

Figure 3-XRD diffraction analysis of Iraqi bentonite.

$\mathrm{XRF}$ analysis is shown in Table-2. The ratio of $\mathrm{Al}_{2} \mathrm{O} 3 / \mathrm{SiO}_{2}$ was $1 / 3$, as expected for montmorillonite which is the main component of bentonite. The ratio of $\left(\mathrm{Na}_{2} \mathrm{O}+\mathrm{K}_{2} \mathrm{O}\right) /(\mathrm{CaO}+\mathrm{MgO})$, based on previously reported approach [21], was found to be 0.143 , confirming that Iraqi bentonite was of Ca-bentonite type.

Table 2 XRF Analysis of Iraqi bentonite

\begin{tabular}{|c|c|c|c|c|c|c|c|c|}
\hline $\begin{array}{c}\mathrm{SiO}_{2} \\
\%\end{array}$ & $\begin{array}{c}\mathrm{Fe}_{2} \mathrm{O}_{3} \\
\%\end{array}$ & $\begin{array}{c}\mathrm{Al}_{2} \mathrm{O}_{3} \\
\%\end{array}$ & $\begin{array}{c}\mathrm{CaO} \\
\%\end{array}$ & $\begin{array}{c}\mathrm{MgO} \\
\%\end{array}$ & $\begin{array}{c}\mathrm{SO}_{3} \\
\%\end{array}$ & $\begin{array}{c}\mathrm{LOI} \\
\%\end{array}$ & $\begin{array}{c}\mathrm{Na}_{2} \mathbf{O} \\
\%\end{array}$ & $\begin{array}{c}\mathrm{K}_{2} \mathrm{O} \\
\%\end{array}$ \\
\hline 52.1 & 5.71 & 15.91 & 7.06 & 1.79 & 0.99 & 13.68 & 0.60 & 0.67 \\
\hline
\end{tabular}

The results of PSD analysis are shown in Fig 4, where $10 \%$ of the particles had a size smaller than $5.354 \mu \mathrm{m}, 50 \%$ smaller than $24.512 \mu \mathrm{m}$, and $90 \%$ smaller than $69.96 \mu \mathrm{m}$. The average particle size of Iraqi bentonite inside the powder was $36.0825 \mu \mathrm{m}$.

The specific surface area (SSA) of Iraqi bentonite diffraction was $0.449 \mathrm{~m}^{2} / \mathrm{g}$. The technique of wet laser diffraction was used to measure the specific surface area depending mainly on particle size [22]. 


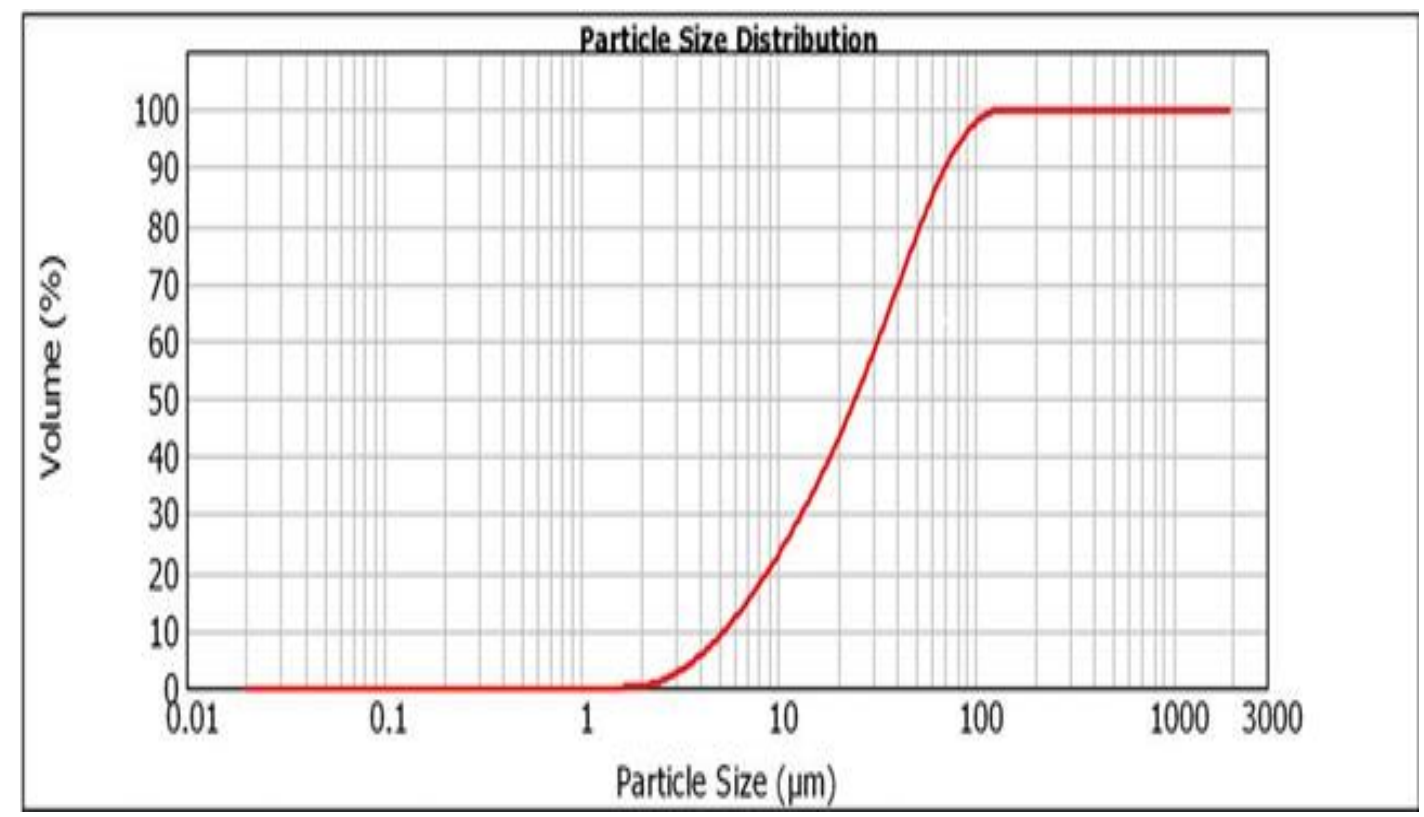

Figure 4-Particle size distributions for Iraqi bentonite.

The rheological properties of Iraqi bentonite and gel strength were very poor as compared with API specifications. The filtration loss was also very high and the stability was very low (Table-3).

The poor properties of Iraqi bentonite included its $\mathrm{Ca}$ - type. Accordingly, Iraqi bentonite is undesired for the use as drilling mud due to low adsorption and swelling values. Therefore, many processes of activation were carried out to enhance its properties.

Table 3-Rheological Properties of Iraqi Bentonite

\begin{tabular}{|c|c|}
\hline Apparent Viscosity (AV), $\mathrm{Cp}$ & 2.27 \\
\hline Plastic Viscosity (PV), $\mathrm{Cp}$ & 2.35 \\
\hline Yield Point (YP), (lb/100ft $\left.{ }^{2}\right)$ & 0.73 \\
\hline YP/PV, (lb/100ft $/ \mathrm{cp})$ & 0.31 \\
\hline 10s gel Strength, $\left(\mathrm{lb} / 100 \mathrm{ft}^{2}\right)$ & 0.8 \\
\hline 10m gel Strength, $\left(\mathrm{lb} / 100 \mathrm{ft}^{2}\right)$ & 1.9 \\
\hline Density, $\mathrm{ppg}$ & 8.6 \\
\hline $\mathrm{pH}$ & 7.1 \\
\hline $\mathrm{V}_{7.5 \mathrm{~m}}, \mathrm{ml}$ & 27 \\
\hline $\mathrm{V}_{30 \mathrm{~m}, \mathrm{ml}}$ & 54 \\
\hline Thickness of Mud Cake, $\mathrm{mm}$ & 2.13 \\
\hline Stability, $2 \mathrm{hs}, \%$ & 76 \\
\hline Stability, $4 \mathrm{hs}, \%$ & 67.2 \\
\hline Stability, $24 \mathrm{hs}, \%$ & 50.8 \\
\hline
\end{tabular}

\section{Effects of Adding $\mathrm{Na}_{2} \mathrm{CO}_{3}$ on Rheological Properties}

Apparent viscosity reflects the flow ability of drilling fluids and is related to the rate of penetration, whereas plastic viscosity is caused by the friction between the suspended particles and influenced by the viscosity of the base liquid [23]. Yield point is an important rheological parameter for drilling fluids and reflects the resistance to initial flow or the stress required to initiate fluid movement. Yield point to plastic viscosity is another important rheological parameter reflecting the capability of carrying drilling cuttings [24]. As shown in Table-4, $\mathrm{Na}_{2} \mathrm{CO}_{3}$ succeeded to enhance the Iraqi bentonite and its rheological properties satisfied the API specifications with the addition of $0.6 \mathrm{~g}$ of $\mathrm{Na}_{2} \mathrm{CO}_{3}$. The rheological properties and gel strength were increased when the concentration of $\mathrm{Na}_{2} \mathrm{CO}_{3}$ was increased. The best result of activation of the Iraqi bentonite was at $0.6 \mathrm{gm}$ of $\mathrm{Na}_{2} \mathrm{CO}_{3}$, because when $0.7 \mathrm{gm}$ of $\mathrm{Na}_{2} \mathrm{CO}_{3}$ was added, the value of YP/PV was approximately higher than the API 
specifications, whereas adding $0.8 \mathrm{gm}$ of $\mathrm{Na}_{2} \mathrm{CO}_{3}$ resulted in higher $\mathrm{YP}, \mathrm{YP} / \mathrm{PV}$ and gel strength values than those of the API specifications.

Table 4-Rheological Properties of the Directly-activated Iraqi bentonite by $\mathrm{Na}_{2} \mathrm{CO}_{3}$

\begin{tabular}{|c|c|c|c|c|c|c|c|}
\hline \multirow{2}{*}{$\begin{array}{l}\mathrm{S} \\
\%\end{array}$} & \multirow{2}{*}{$\begin{array}{l}\text { Wt. } \\
\text { gm }\end{array}$} & \multirow{2}{*}{$\begin{array}{l}\text { AV } \\
\text { cp }\end{array}$} & \multirow{2}{*}{$\begin{array}{l}\text { PV } \\
\text { cp }\end{array}$} & \multirow{2}{*}{$\underset{\left(\mathbf{l b} / \mathbf{1 0 0} / \mathbf{f t}^{2}\right)}{\mathbf{Y P}}$} & \multirow{2}{*}{$\begin{array}{c}\text { YP/PV } \\
\left(\mathbf{l b} / 100 f^{2} / c p\right)\end{array}$} & \multicolumn{2}{|c|}{$\begin{array}{c}\text { Gel Strength } \\
\left(\mathbf{l b} / \mathbf{1 0 0 f t ^ { 2 } )}\right.\end{array}$} \\
\hline & & & & & & $10 \mathrm{~s}$ & $10 \mathrm{~m}$ \\
\hline 0.1 & 0.4 & 3.62 & 1.91 & 3.41 & 1.78 & 2 & 4.3 \\
\hline 0.13 & 0.5 & 8.94 & 3.62 & 10.65 & 2.94 & 10.1 & 11.7 \\
\hline 0.16 & 0.6 & 20.18 & 4.68 & 30.99 & 6.62 & 33.7 & 49.4 \\
\hline 0.18 & 0.7 & 24.55 & 4.8 & 39.5 & 8.23 & 39.3 & 50.7 \\
\hline 0.21 & 0.8 & 31.3 & 5 & 52.6 & 10.52 & 49.7 & 62.9 \\
\hline
\end{tabular}

Figure-5 elucidates the rheological properties of the Iraqi bentonite directly-activated with different weights of $\mathrm{Na}_{2} \mathrm{CO}_{3}$. It shows that all the rheological properties were increased as the weight of $\mathrm{Na}_{2} \mathrm{CO}_{3}$ was increased. The increase in mass concentration has to improve the apparent viscosity because of the higher interaction between clay particles [25]. This refers to an increase of solid particles in liquid that increases electrochemical or attraction forces in the liquid [26]. The rheological properties were increased because of increasing $\mathrm{Na}^{+}$concentration which resulted in an increased cation exchange capacity between $\mathrm{Na}^{+}$and $\mathrm{Ca}^{++}$and swelling capacity of the activated bentonite. $\mathrm{Na}_{2} \mathrm{CO}_{3}$ possibly interacted with $\mathrm{Ca}$ in the Iraqi bentonite, and the result of the interaction was the formation of Na-bentonite and $\mathrm{CaCO}_{3}$, which is the white solid material deposited in the bottom of the drilling mud.

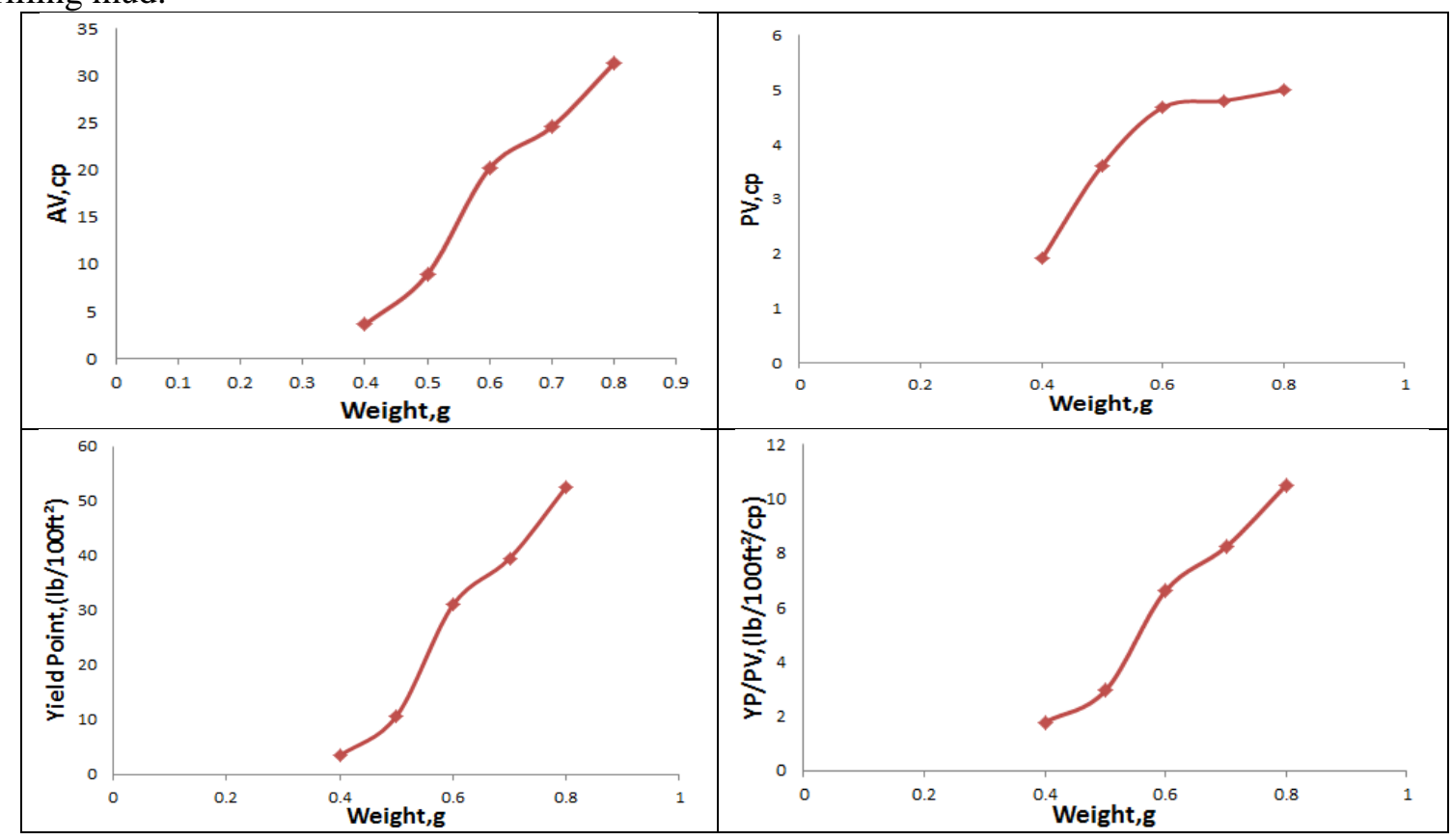

Figure 5-Rheological Properties of Iraqi Bentonite Directly-activated by $\mathrm{Na}_{2} \mathrm{CO}_{3}$.

\section{Effects of Adding $\mathrm{Na}_{2} \mathrm{CO}_{3}$ on Stability Measurements}

Table-5 manifests the stability of the activated Iraqi bentonite after directly adding different weight of $\mathrm{Na}_{2} \mathrm{CO}_{3}$. The table shows a large difference in the stability of the activated bentonite compared with that before activation. The remarkable enhancement in stability indicated that the substitution between $\mathrm{Na}$ and $\mathrm{Ca}$ cations made the Iraqi bentonite highly adsorbed in water. Therefore, the activation was successful. 
Table 5-Stability of Iraqi Bentonite Directly-activated by $\mathrm{Na}_{2} \mathrm{CO}_{3}$

\begin{tabular}{|c|c|c|c|c|}
\hline \multirow{2}{*}{$\begin{array}{c}\text { St. } \\
\text { \% }\end{array}$} & \multirow{3}{*}{$\begin{array}{c}|c| \\
\text { gm }\end{array}$} & \multicolumn{3}{|c|}{$\begin{array}{c}\text { Stability } \\
\text { \% }\end{array}$} \\
\cline { 3 - 5 } & & $\mathbf{1 ~ h r}$ & $\mathbf{2 ~ h r}$ & $\mathbf{2 4} \mathbf{~ h r}$ \\
\hline 0.10 & 0.4 & 97.2 & 95.2 & 83.2 \\
\hline 0.13 & 0.5 & 98.3 & 97.6 & 90.5 \\
\hline 0.16 & 0.6 & 98.8 & 97.9 & 95.4 \\
\hline 0.18 & 0.7 & 100 & 100 & 100 \\
\hline 0.21 & 0.8 & 100 & 100 & 100 \\
\hline
\end{tabular}

\section{Effects of Adding Na2CO3 on pH, Density and Filtration Properties}

As demonstrated in Table- 6 , the density was approximately constant and not affected by increasing the weight of $\mathrm{Na}_{2} \mathrm{CO}_{3}$. The $\mathrm{pH}$ value was increased from 8.8 to 9.92 when $\mathrm{Na}_{2} \mathrm{CO}_{3}$ addition was increased from $0.4 \mathrm{gm}$ to $0.8 \mathrm{gm}$, because sodium carbonate dissolution in water causes the $\mathrm{pH}$ to increase. This high $\mathrm{pH}$ value is used to distinguish activated from non-activated materials [27]. The filtration property of drilling mud is the measure of the ability of its solid components to form a thin, low permeable filter cake. Low permeability decreases drilling difficulties because a thick filter cake restricts the passage of tools and allows an excessive amount of filtrate to pass into the formation, thus causing a cave [28]. Also, the results from this table reveal that the filtration volume had a high filter loss and that the mud cake was approximately thick because the activating material $\left(\mathrm{Na}_{2} \mathrm{CO}_{3}\right)$ does not work on filtration enhancement. Therefore, filtration properties failed to meet the API standards.

Because the filtration properties were not enhanced, $1,1.5$ and $2 \mathrm{gm}$ of CMC-LV were added to enhance the results of direct activation of Iraqi bentonite by $\mathrm{Na}_{2} \mathrm{CO}_{3}\left(0.7 \mathrm{gm}\right.$ of $\mathrm{Na}_{2} \mathrm{CO}_{3}$ were added to $22.5 \mathrm{gm}$ bentonite with $350 \mathrm{ml}$ of distilled water).

Table 6-Density, $\mathrm{pH}$ and Filtration Properties of Iraqi Bentonite Directly-activated by $\mathrm{Na}_{2} \mathrm{CO}_{3}$

\begin{tabular}{|c|c|c|c|c|c|c|}
\hline $\begin{array}{c}\mathbf{S} \\
\mathbf{\%}\end{array}$ & $\begin{array}{c}\mathbf{W t .} \\
\mathbf{g m}\end{array}$ & $\begin{array}{c}\text { Density } \\
\mathbf{p p g}\end{array}$ & $\mathbf{p H}$ & $\begin{array}{c}\mathbf{V}_{\mathbf{7 . 5 m}} \\
\mathbf{m l}\end{array}$ & $\begin{array}{c}\mathbf{V}_{\mathbf{3 0 m}} \\
\mathbf{m l}\end{array}$ & $\begin{array}{c}\text { Thickness of } \\
\text { Mud Cake } \\
\mathbf{m m}\end{array}$ \\
\hline 0.10 & 0.4 & 8.5 & 8.8 & 27.3 & 54.6 & 3.6 \\
\hline 0.13 & 0.5 & 8.55 & 9.15 & 20.3 & 40.6 & 3.2 \\
\hline 0.16 & 0.6 & 8.55 & 9.27 & 16.4 & 32.8 & 4.7 \\
\hline 0.18 & 0.7 & 8.55 & 9.48 & 14.1 & 28.2 & 5.2 \\
\hline 0.21 & 0.8 & 8.55 & 9.92 & 11.5 & 23 & 6.5 \\
\hline
\end{tabular}

Fig 6 shows the results of the swelling test of Iraqi bentonite before activation and after the best result of direct activation by $\mathrm{Na}_{2} \mathrm{CO}_{3}$. Also, this figure shows that the value of the swelling index of the best result of direct activation process was $20 \mathrm{ml}$, which is considered an accepted value. This value of swelling index provided the indication of the type of bentonite, since Na-bentonite has a high swelling capacity and Ca-bentonite has a low swelling capacity. From this figure, the value of swelling index of the best result of direct activation indicated that the activation process was successful and Iraqi bentonite was converted from Ca-bentonite to Na-bentonite, as indicated by the highest swelling capacity that the bentonite acquired after the direct activation process. 


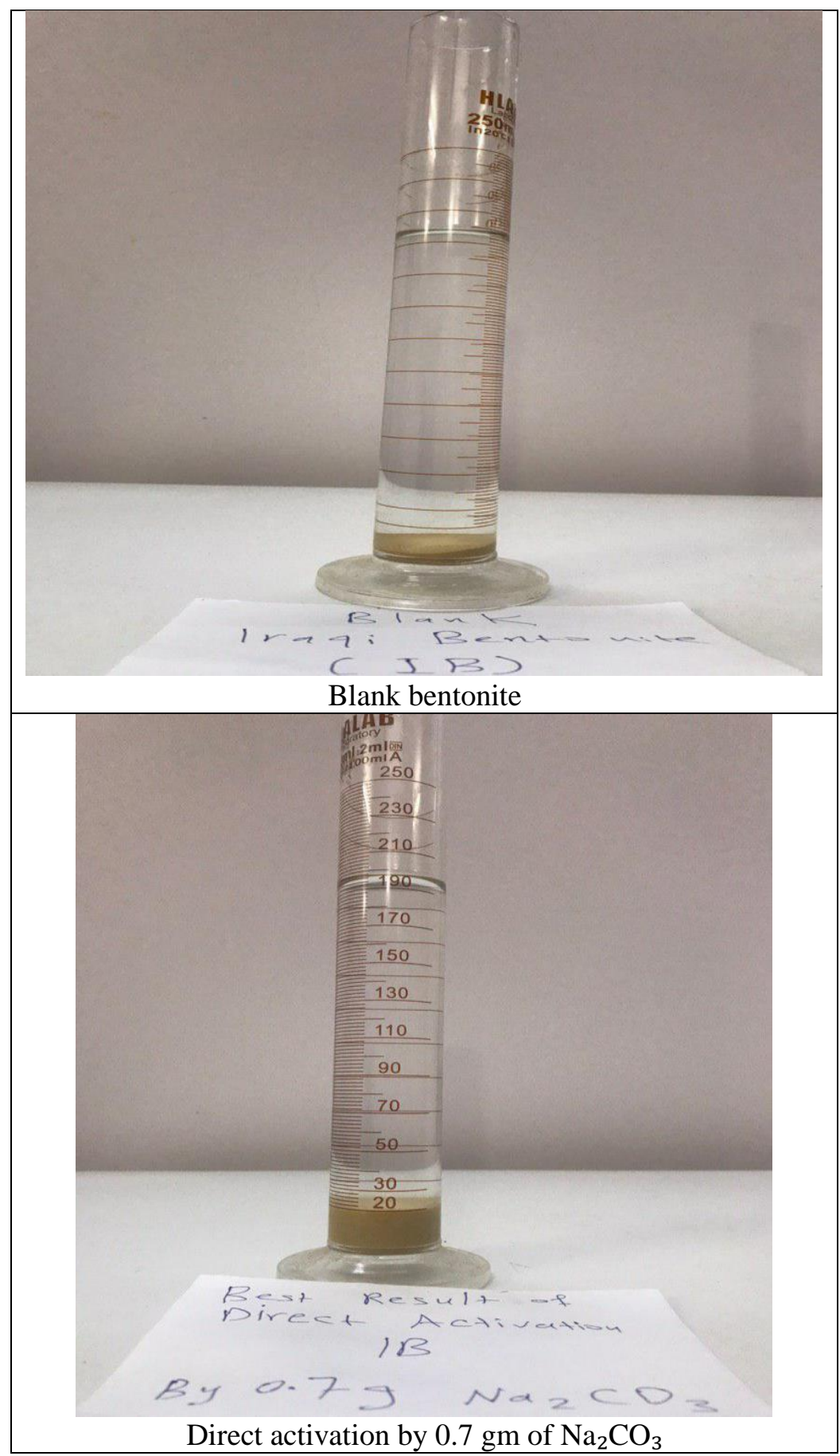

Figure 6-Swelling Test of Iraqi bentonite before Activation and after the Best Result of Direct Activation by $\mathrm{Na}_{2} \mathrm{CO}_{3}$

\section{XRF Characterization of Bentonite after Adding $\mathrm{Na}_{2} \mathrm{CO}_{3}$}

The results of XRF analysis (Table-7) show that the ratio of $\left(\mathrm{Na}_{2} \mathrm{O}+\mathrm{K}_{2} \mathrm{O}\right) /(\mathrm{CaO}+\mathrm{MgO})$ in the activated bentonite was 1.07 , confirming that the direct activation process was successful and the bentonite was converted from Ca-bentonite to Na-bentonite.

The results showed that $10 \%$ of particles had a sizes under $4.66 \mu \mathrm{m}, 50 \%$ under $10.403 \mu \mathrm{m}$, and $90 \%$ under $21.791 \mu \mathrm{m}$ (Figure-7). The decrease in particle size led to an increase in clay surface area. The value of the specific surface area was $0.577 \mathrm{~m}^{2} / \mathrm{g}$. This value was higher than the value of clay before activation. 


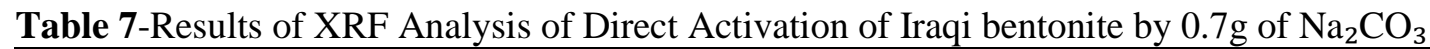

\begin{tabular}{|c|c|c|c|c|c|c|c|c|c|}
\hline $\begin{array}{c}\mathrm{SiO}_{\mathbf{2}} \\
\mathbf{\%}\end{array}$ & $\begin{array}{c}\mathbf{F e}_{\mathbf{2}} \mathbf{O}_{\mathbf{3}} \\
\mathbf{\%}\end{array}$ & $\begin{array}{c}\mathrm{Al}_{\mathbf{2}} \mathbf{O}_{\mathbf{3}} \\
\mathbf{\%}\end{array}$ & $\begin{array}{c}\mathbf{C a O} \\
\mathbf{\%}\end{array}$ & $\begin{array}{c}\mathbf{M g O} \\
\mathbf{\%}\end{array}$ & $\begin{array}{c}\mathbf{S O}_{\mathbf{3}} \\
\mathbf{\%}\end{array}$ & $\begin{array}{c}\mathbf{T i O}_{\mathbf{\%}} \\
\mathbf{\%}\end{array}$ & $\begin{array}{c}\mathbf{N a}_{\mathbf{2}} \mathbf{O} \\
\mathbf{\%}\end{array}$ & $\begin{array}{c}\mathbf{K}_{\mathbf{2}} \mathbf{O} \\
\mathbf{\%}\end{array}$ & $\begin{array}{c}\mathbf{P}_{\mathbf{2}} \mathbf{O}_{\mathbf{5}} \\
\mathbf{\%}\end{array}$ \\
\hline 44.64 & 5.52 & 10.65 & 13.28 & 2.8 & 3.64 & 0.98 & 16.59 & 0.57 & 0.57 \\
\hline
\end{tabular}

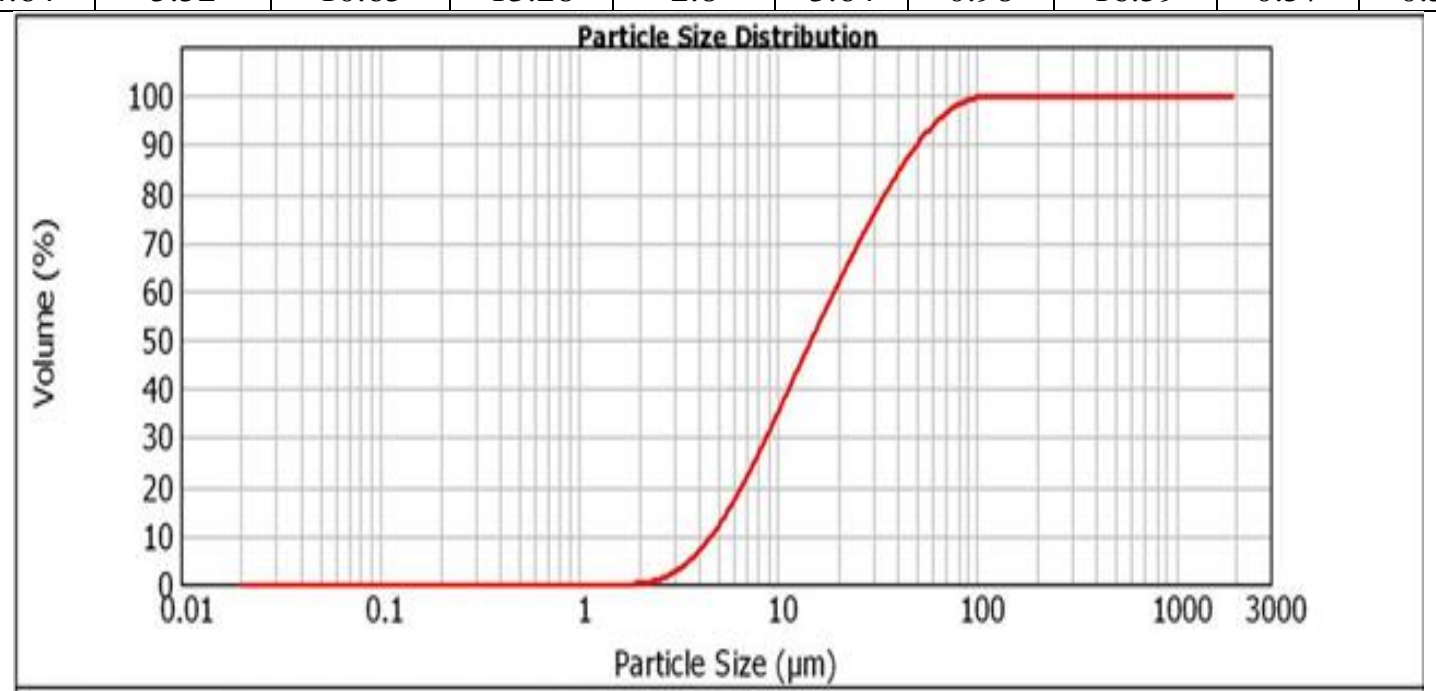

Figure 7-Particle Size Distribution of Directly-activated Iraqi bentonite by $\mathrm{Na}_{2} \mathrm{CO}_{3}$.

\section{Effects of Adding CMC-HV on rheological properties}

Table- 8 shows the rheological properties of Iraqi bentonite after adding different weights of CMC$\mathrm{LV}$ (filtration reducer material) and $0.7 \mathrm{gm}$ of $\mathrm{Na}_{2} \mathrm{CO}_{3}$ (activation material) to the API standard mixture ( $22.5 \mathrm{gm}$ of bentonite $+350 \mathrm{ml}$ of distilled water). It reveals that the apparent viscosity did not satisfy the API specification and was decreased compared with that of the best mixture of direct activation of Iraqi bentonite by $\mathrm{Na}_{2} \mathrm{CO}_{3} .1 \mathrm{gm}$ was adopted as the best result of adding CMC-LV to the best result of direct activation of Iraqi bentonite by $\mathrm{Na}_{2} \mathrm{CO}_{3}$. The purpose of adding CMC-LV was to enhance the filtration volume and the thickness of mud cake. In fact, the effect of CMC-LV was not only on the filtration properties but also on the rheological properties. Thus, different weights of CMC-HV were added to the mixture of $1 \mathrm{gm}$ of CMC-LV and the best result of direct activated Iraqi bentonite by $\mathrm{Na}_{2} \mathrm{CO}_{3}$ in order to enhance the rheological and filtration properties.

Table 8-Rheological Properties after Adding CMC-LV to the Best Mixture of Direct Activation by $\mathrm{Na}_{2} \mathrm{CO}_{3}$

\begin{tabular}{|c|c|c|c|c|c|c|c|}
\hline \multirow[t]{2}{*}{$\begin{array}{l}\mathbf{S} \\
\%\end{array}$} & \multirow[t]{2}{*}{$\begin{array}{l}\text { Wt. } \\
\text { gm }\end{array}$} & \multirow[t]{2}{*}{$\begin{array}{l}\text { AV } \\
\text { cp }\end{array}$} & \multirow[t]{2}{*}{$\begin{array}{l}\text { PV } \\
\text { cp }\end{array}$} & \multirow[t]{2}{*}{$\begin{array}{c}\text { YP } \\
\left(\mathbf{l b} / \mathbf{1 0 0 f t ^ { 2 } )}\right.\end{array}$} & \multirow[t]{2}{*}{$\begin{array}{c}\text { YP/PV } \\
\left(\mathbf{l b} / \mathbf{1 0 0 f t ^ { 2 } / c p )}\right.\end{array}$} & \multicolumn{2}{|c|}{$\begin{array}{c}\text { Gel Strength } \\
\left(\mathbf{l b} / \mathbf{1 0 0 \mathbf { f t } ^ { 2 } )}\right.\end{array}$} \\
\hline & & & & & & $10 \mathrm{~s}$ & $10 \mathrm{~m}$ \\
\hline 0.26 & 1 & 9.3 & 6.9 & 4.9 & 0.71 & 1 & 22.9 \\
\hline 0.4 & 1.5 & 7.8 & 5.1 & 5.4 & 1.06 & 2.1 & 27.4 \\
\hline 0.53 & 2 & 3.3 & 2.9 & 0.8 & 0.28 & 0.4 & 0.3 \\
\hline
\end{tabular}

Figure-8 shows that the values of the rheological properties were decreased when the weight of the added CMC-LV was increased, because CMC-LV worked on reducing rheological properties and enhancing the filtration properties by reducing the volume of filtration and thickness of mud cake. 


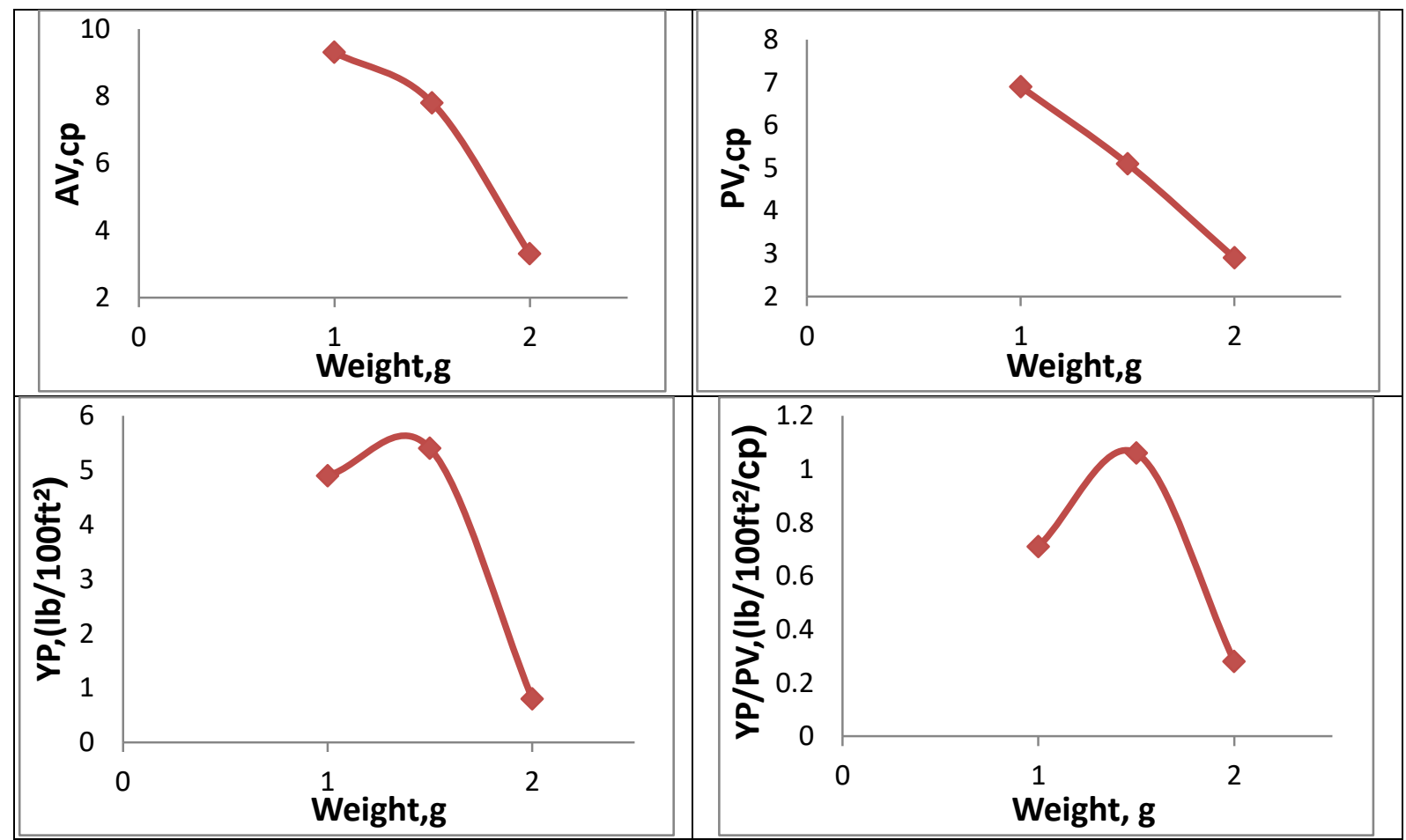

Figure 8-Rheological Properties of Iraqi bentonite after Adding CMC-LV to the Best Mixture of Direct Activation by $\mathrm{Na}_{2} \mathrm{CO}_{3}$.

\section{Effects of Adding CMC-HV on pH, Density and Filtration Properties}

Table-9 shows that the density and $\mathrm{pH}$ values were approximately constant and were not affected by the addition of CMC-LV. The filtration properties of Iraqi bentonite after adding different weights of CMC-LV and $0.7 \mathrm{gm}$ of $\mathrm{Na}_{2} \mathrm{CO}_{3}$ to the API standard mixture were enhanced and satisfied the API specifications compared with those of the best result of direct activation of Iraqi bentonite by $\mathrm{Na}_{2} \mathrm{CO}_{3}$ without adding CMC-LV.

Table 9-Density, $\mathrm{pH}$ and Filtration Properties after Adding CMC-LV to the Best Mixture of Direct Activation of Iraqi bentonite by $\mathrm{Na}_{2} \mathrm{CO}_{3}$

\begin{tabular}{|c|c|c|c|c|c|c|}
\hline $\begin{array}{c}\mathbf{S} \\
\mathbf{\%}\end{array}$ & $\begin{array}{c}\mathbf{W t .} \\
\mathbf{g m}\end{array}$ & $\begin{array}{c}\text { Density } \\
\mathbf{p p g}\end{array}$ & $\mathbf{p H}$ & $\begin{array}{c}\mathbf{V}_{7.5 \mathbf{m}} \\
\mathbf{m l}\end{array}$ & $\begin{array}{c}\mathbf{V}_{\mathbf{3 0 m}} \\
\mathbf{m l}\end{array}$ & $\begin{array}{c}\text { Thickness of Mud } \\
\text { Cake } \\
\mathbf{m m}\end{array}$ \\
\hline 0.26 & 1 & 8.55 & 8.5 & 6.9 & 13.8 & 0.61 \\
\hline 0.4 & 1.5 & 8.6 & 8.55 & 5.6 & 11.2 & 0.53 \\
\hline 0.53 & 2 & 8.61 & 8.57 & 5.5 & 11 & 0.51 \\
\hline
\end{tabular}

\section{Effects of Adding CMC-LV on Rheological Properties}

Table-10 shows the rheological properties of Iraqi bentonite after adding $1 \mathrm{~g}$ of CMC-LV, $0.7 \mathrm{~g}$ of $\mathrm{Na}_{2} \mathrm{CO}_{3}$, and different weights of CMC-HV to API standard mixture (22.5 gm of Iraqi bentonite and $350 \mathrm{ml}$ of distilled water). The results demonstrate that, as the weight of CMC-HV was increased, the rheological properties were increased and had an accepted value at the weight of 2 gm of CMC-HV. At the same time, the filtration properties satisfied the API specifications. Therefore, the best mixture was achieved when $1 \mathrm{gm}$ of CMC-LV, $2 \mathrm{gm}$ of CMC-HV, and $0.7 \mathrm{gm}$ of $\mathrm{Na}_{2} \mathrm{CO}_{3}$ were added for enhancing the rheological as well as filtration properties. This indicates that the Iraqi bentonite is sufficient to be used as drilling fluid. The same weights of CMC-LV and CMC-HV can be used for the direct activation of Iraqi bentonite by $\mathrm{NaOH}$. 
Table 10-Rheological Properties after Adding CMC-HV and CMC-LV to the Best Mixture of Direct Activation by $\mathrm{Na}_{2} \mathrm{CO}_{3}$

\begin{tabular}{|c|c|c|c|c|c|c|c|}
\hline \multirow{2}{*}{$\begin{array}{c}S \\
\%\end{array}$} & \multirow{2}{*}{$\begin{array}{l}\text { Wt. } \\
\text { Gm }\end{array}$} & \multirow{2}{*}{$\begin{array}{l}\text { AV } \\
\text { Cp }\end{array}$} & \multirow{2}{*}{$\begin{array}{l}\text { PV } \\
\text { cp }\end{array}$} & \multirow{2}{*}{$\begin{array}{c}\text { YP } \\
\left(\mathbf{l b} / \mathbf{1 0 0 f t ^ { 2 }}\right)\end{array}$} & \multirow{2}{*}{$\begin{array}{c}\text { YP/PV } \\
\left(\mathbf{l b} / 100 f^{2} / c p\right)\end{array}$} & \multicolumn{2}{|c|}{$\begin{array}{c}\text { Gel Strength } \\
\left(\mathbf{l b} / \mathbf{1 0 0 f t ^ { 2 } )}\right.\end{array}$} \\
\hline & & & & & & $10 \mathrm{~s}$ & $10 \mathrm{~m}$ \\
\hline 0.13 & 0.5 & 14.4 & 8.5 & 5.6 & 0.67 & 0.3 & 0.7 \\
\hline 0.26 & 1 & 16 & 11.76 & 8.48 & 0.72 & 0.5 & 11.5 \\
\hline 0.53 & 2 & 37.81 & 22.8 & 30.02 & 1.32 & 7.2 & 46.6 \\
\hline
\end{tabular}

Figure-9 shows that the apparent viscosity was increased when the weight of CMC-HV was increased. The best rheological properties were achieved when $2 \mathrm{gm}$ of CMC-HV was added to the mixture ( $1 \mathrm{gm}$ of CMC-LV, $0.7 \mathrm{gm}$ of $\mathrm{Na}_{2} \mathrm{CO}_{3}, 22.5 \mathrm{gm}$ of Iraqi bentonite and $350 \mathrm{ml}$ of distilled water), which satisfied the API specification.

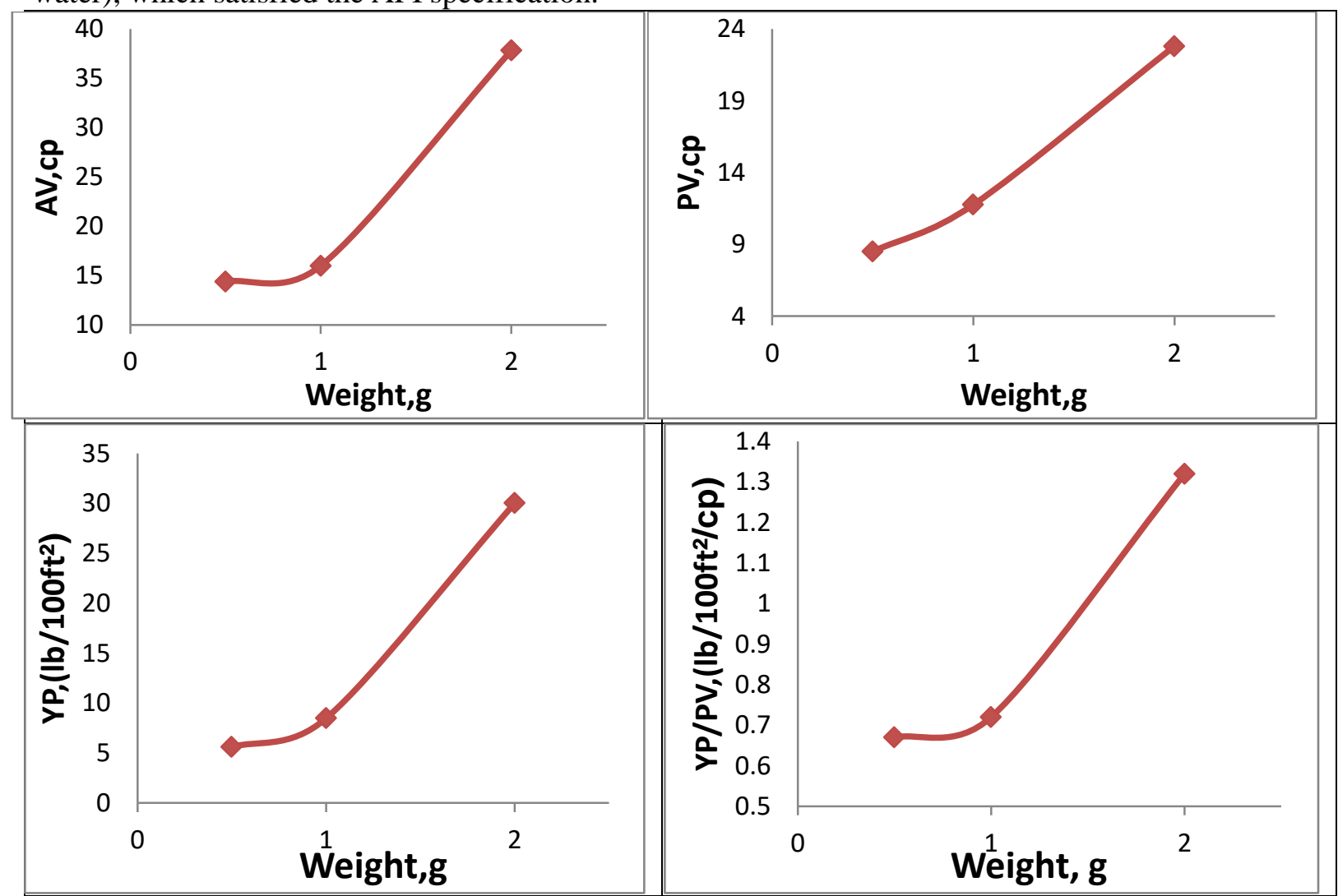

Figure 9-Rheological Properties of Iraqi bentonite after Adding CMC-HV and CMC-LV to the Best Mixture of Direct Activation by $\mathrm{Na}_{2} \mathrm{CO}_{3}$.

\section{Effects of Adding CMC-LV on pH, Density and Filtration Properties}

Table-11 depicts the density, $\mathrm{pH}$, and filtration properties of Iraqi bentonite after adding $1 \mathrm{gm}$ of CMC-LV, $0.7 \mathrm{~g}$ of $\mathrm{Na}_{2} \mathrm{CO}_{3}$, and different weights of CMC-HV to the API standard mixture (22.5 gm of Iraqi bentonite and $350 \mathrm{ml}$ of distilled water). The table shows that the values of volume filtration and thickness of the mud cake meet the API specifications and, hence, they are accepted. and the properties of the produced mud cake were largely enhanced compared with those of the best mixture of direct activation of Iraqi bentonite by $\mathrm{Na}_{2} \mathrm{CO}_{3}$ without adding CMC-HV and CMC-LV. 
Table 11-Density, $\mathrm{pH}$ and Filtration Properties after Adding CMC-HV and CMC-LV to the Best Mixture of Direct Activation of Iraqi bentonite by $\mathrm{Na}_{2} \mathrm{CO}_{3}$

\begin{tabular}{|c|c|c|c|c|c|c|}
\hline $\begin{array}{c}\mathbf{S} \\
\mathbf{\%}\end{array}$ & $\begin{array}{c}\text { Wt. } \\
\mathbf{g m}\end{array}$ & $\begin{array}{c}\text { Density } \\
\mathbf{p p g}\end{array}$ & $\mathbf{p H}$ & $\begin{array}{c}\mathbf{V}_{\mathbf{7 . 5 m}} \\
\mathbf{m l}\end{array}$ & $\begin{array}{c}\mathbf{V}_{\mathbf{3 0 m}} \\
\mathbf{m l}\end{array}$ & $\begin{array}{c}\text { Thickness of } \\
\text { Mud Cake } \\
\mathbf{m m}\end{array}$ \\
\hline 0.13 & 0.5 & 8.5 & 9.5 & 6.7 & 13.4 & 0.54 \\
\hline 0.26 & 1 & 8.55 & 9.6 & 5.1 & 10.2 & 0.58 \\
\hline 0.53 & 2 & 8.5 & 9.6 & 3.9 & 7.8 & 0.67 \\
\hline
\end{tabular}

\section{Conclusions}

This research was conducted to enhance and activate Iraqi bentonite (converting it from Ca-type to Na-type) in samples collected from Trefawi formation/ Al-Anbar region/ Iraq. The rheological and filtration properties were enhanced and the quality was increased in order to use the product in Iraqi Oil Companies instead of commercial bentonite.

Iraqi bentonite was successfully activated by adding $\mathrm{Na}_{2} \mathrm{CO}_{3}$ because of increasing the mass concentration which led to increase the amount of clay particles. Therefore, the rheological and stability properties were enhanced in a manner that fulfilled API specifications.

The filtration properties of Iraqi bentonite failed to enhance after adding $\mathrm{Na}_{2} \mathrm{CO}_{3}$.

The Filtration properties were enhanced by adding $1 \mathrm{gm}$ of CMC-LV and $2 \mathrm{gm}$ of CMC-HV to the mixture of the best result of direct activation by $\mathrm{Na}_{2} \mathrm{CO}$. As a result, Iraqi bentonite showed better properties to be used as drilling fluid in Iraqi oil companies instead of commercial bentonite, because its properties were enhanced in a manner that meets API specifications.

\section{References}

1. Dardir, M.M., Awadallah, I. A., Abd El-Wahab, S. I. and Al-Shefey, H. I. 2016. Improvement the rheological properties of local bentonite clay using new blending polymers for water-based drilling fluids Egyptian Journal of Chemistry, 59(1):59-78.

2. Wilfred, O. C., and Akinada, A. E. 2016. Comparative Study of Basic Properties of Mud Prepared with Nigerian Local Clay and Mud Prepared with Foreign Clay; A Case of Abbi Clay Deposit, International Journal of Engineering and Technologies, 8: 61-71.

3. Erdogan B and Demirci S 1996 Activation of some Turkish bentonite to improve their drilling Fluid properties, Applied Clay Science, 10401-10410.

4. Murray, H. H. 2000. Traditional and New Applications for Kaolin, Smectite, and Palygorskite, A General Overview, Applied Clay Science, 17: 207-221.

5. Murray, H. 2002. Industrial Clays Case Study, International Institute for Environments and Development, 64: 1-9.

6. Nawasreh M. 2015. Bentonite, Ministry of Energy and Mineral Resoueces Mineral Status and Future Opportunuty, 1-35.

7. Naswir, M., Arita, S., Marsi, and Salni. 2014. Activation of Bentonite and Application for Reduction pH, Color, Organic Substance, and Iron (Fe) in the Peat Water, Science Journal of Chemistry, 1(5):74-82.

8. Magzoup, M. I., Nasser, M. S., Hussein, I. A., Benamour, A., Onaizi, S. A., Sultan, A. S., and Mahmoud, M. A. 2017. Effects of sodium carbonate addition, heat and agitation on swelling and rheological behavior of Ca-bentonite colloidal dispersions, Applied Clay Science, 1-8.

9. Kern, R. 1988. Rheology of aqueous suspension of sodium/calcium montmorillonite, Soil Science Society of American Journal, 52: 924-928.

10. Karagüzel, C., Çetinel, T., Boylu, F., Çinku, K. and Çelik, M. S. 2010. Activation of (Na,Ca)bentonites with soda and $\mathrm{MgO}$ and their utilization as drilling mud, Applied Clay Science, $\mathbf{4 8}$ : 398-404.

11. Al-Ajeel, A.A., Kshash, J.M. and Mahdi, S.N. 2013. Sodium Activation of Iraqi High Grade MontmorilloniteClaystone by Dry Method, Iraqi Bulletin of Geology and Mining, 9(1): 65-73.

12. Rasin F. A., and Hamad E. A. 2013. Study on the activation of QaraTappah Iraqi bentonite and its test as gelling agent, International Journal of Application or Innovation in Engineering \& Management (IJAIEM), 2:1-4. 
13. Önal, M. and Sarikaya, Y. 2007. Preparation and characterization of acid-activated bentonite powders, Powder Technology, 172: 14-18.

14. Al-Essa, K. 2018. Activation of Jordanian bentonite by Hydrochloric acid and its potential for olive mill wastewater enhanced treatment, Journal of Chemistry, 15(2): 1-10.

15. Hameed, M.S. 2018. Improving Drilling Fluid Lubricity Using Nanomaterials, Thesis, University of Technology, Iraq.

16. Inglethrope, S. D. J., Morgan, D. J., Highley, D. E., and Bloodworth, A. J. 1993. Industrial Minerals laboratory Manual (Bentonite), British Geological Survey, 1-20.

17. Khan, k., Khan, S. A., Saleem, M. U. and Ashraf, M. 2017. Improvement of locally available raw bentonite for use as drilling mud, The Open Construction and Building Technology Journal, 11: 274-284.

18. Winer, A. A. 1954. Acid Activation of Saskatchewan Bentonite. Canada. Industrial Minerals Research Branch, Report of Investigations, 4: 1-29.

19. Erdoğan, B., and Demirci, S. 1996. Activation of Some Turkish Bentonites to Improve their Drilling Fluid Properties, Applied Clay Science, 10: 401-410.

20. Agwu, O. E., Okon, A. N. and Akpanika, O. I. 2016. Activation of local bentonite clays for use as viscofiers in water-based drilling fluids, Journal of Scientific Researchs\& Reports(JSRR), 12(11): 2320-0227.

21. Abdou, M. I., Al-sabagh, A. M., and Dardir, M. I. 2013. Evaluation of Egyptian Bentonite and Nano-Bentonite as Drilling Mud, Egyptian Journal of Petroleum, 22: 53-59.

22. Gomez-Tena, M. P., Gilabert, J., Toledo, J., Zumaquero, E. and Machi, C. 2014. Relationship between the specfic surface area parameters determined using different alalytical techniques, Qualicer, 14: 1-10.

23. Faloda, O. A., Ehinola, O. A. and Nebeife, P. C. 2008. Evaluation of Local Bentonite Clay as Oil Well Drilling Fluid in Nigeria, Applied Clay Science, 39: 19-27.

24. Meng X., Zhang Y., Zhou F., and Chu P. K. 2012. Effects of Carbon Ash on Rheological Properties of Water-Based Drilling Fluids, Journal of Petroleum Science and Engineering, 100: 18.

25. Boussen, S., Sghaier, D., Chaabani, F., Jamoussi, B., and Bennour, A. 2015. The rheological, mineralogical and chemical characteristic of the original and the $\mathrm{Na}_{2} \mathrm{CO}_{3}$-activated Tunisian swelling clay (Aleg Formation) and their utilization as drilling mud, Applied Clay Science, 1-10.

26. Hussein, R. A. M., Elemam, A. E., Mohamed, S. A., and Ibrahim, A. A. 2014. Assessment of the Increasing Local Bentonite Concentration on Drilling Fluids Rheology and Filtration Properties, SUST Journal of Engineering and Computer Science (JECS), 15(2): 1-34.

27. Kaufhold S., Emmerich K., Dohrmann R., Steudel A. and Ufer K. 2013. Comparison of methods for distinguishing sodium carbonate activated from natural sodium bentonites, Applied Clay Science, 86: 23-37.

28. Abdulkadir, A., Osawemenze, L. A. and Adogbo, G. M. 2013. Rheological and Filtration Properties of Kaolinite Based Drilling Mud, International Journal of Scientific and Engineering Research, 4: 2114-2119. 